Readmission with strings

\section{Athens}

THE World Psychiatric Association (WPA) last week voted to readmit the Soviet All-Union Society of Psychiatrists and Narcologists to conditional membership. But despite the overwhelming vote in favour (291 for, 45 against and 19 abstentions), the readmission was not smooth.

The vote was plainly a consequence of tough bargaining. During the meeting, the All-Union society read out a statement acknowledging that there had previously been psychiatric abuses for non-medical, including political, reasons.

Western human rights campaigners, notably the International Association on the Political Use of Psychiatry, described as largely cosmetic the reforms introduced in the Soviet Union in the past five years, when patients' rights to appeal against involuntary hospitalization have been strengthened, the 'special' psychiatric hospitals have been transferred from the prison service to the Ministry of Health and open discussion of Jung and Freud has been allowed.

In particular, the British Royal College of Psychiatrists was still, last week, seeking a formal retraction of the Soviet charge of slander, while WPA itself was criticized for having failed to put forward an application for membership from the Independent Psychiatric Association, the unofficial alternative to the All-Union society.

In the event, the unofficial body was granted unconditional membership, but the All-Union association will be monitored continuously by the WPA review committee; it was warned, last week, that the continuation of abuses may lead to another expulsion. The Bulgarian and Czechoslovak associations returned almost unnoticed to the fold, but the Cuban association, whose government has little time for perestroika, did not apply for renewed membership.

The readmission of the Soviet association to the club was the decision of the WPA General Assembly, which spent much of last week wrestling with ethical issues. Should the suicide of patients be considered 'rational'? What are the rights of third parties providing funds, governments or insurance companies, in the therapeutic process? And what if a genetic basis is established for psychiatric illness? Sir Martin Roth of the Cambridge Clinical School, argued in his closing address that the benefits of such a facility would be offset, at least in part, by the dangers of abuse. Roth particularly emphasized that awareness of the genetic background of psychiatric illness should not lead to prejudice against the carriers of these genes.

Vera Rich

\title{
Death-knell for LD50?
}

\section{London}

BELIEVING that a more humane alternative now exists, the European Commission has decided to put a stop to the assessment of the toxicity of chemicals by the present LD50 (lethal dose - 50 per cent) criterion, in the determination of which large numbers of animals are killed. The criterion is at present given statutory backing by European legislation dealing with the safety of medicines and the introduction of new chemicals into the environment.

After a two-day meeting in Brussels, a senior Commission spokesman said the LD50 system, which has been used since the $1920 \mathrm{~s}$, should be replaced, after a $£ 500,000$ validation programme, by a "fixed-dose" criterion. Dr Michael Balls, from the University of Nottingham Medical School, said the meeting had ended in a mood of great optimism. He applauded the Commission's decision and said that other countries in the Organization for Economic Cooperation and Development (OECD) now using the LD50 criterion should adopt the proposed new system.

LD-50 trials, in which varied doses of chemicals are given to groups of animals so as to determine what dose kills half of a group, have long been condemned by animal rights groups. The criterion was adopted in 1985 by the OECD countries, but in 1987 the guidelines were changed to reduce the number of animals needed, although the principle remained the same.

Balls, who is also a trustee of the Fund for the Replacement of Animals in Medical Experiments (FRAME), says that the more efficient fixed dose formula would reduce the use of experimental animals. "A good toxicologist can administer a fixed dose, depending on what is known about the drug, and judge the toxicity of a chemical by the animal's response", he said.

The validation studies on the fixed-dose criterion, initiated by the UK Home Office and Department of Health with the European Commission, have been carried out in 31 laboratories in Europe, Japan and the United States. At the Brussels meeting, the Commission was presented with results demonstrating the feasibility of the fixed dose procedure. According to Balls, a senior Commission spokesman said he was "convinced" that the method would work and that the Commission was "determined" to see it put into practice.

The Commission must now persuade the OECD countries outside Europe to accept the new guidelines; Sweden and Switzerland gave their approval at the meeting. "The European Commission has thrown down the gauntlet to the US and Japan". Balls added: "It is no longer a question of science, it is now up to the politicians".

\section{Laboratory directors fight bureaucrats}

\section{New Delhi}

A NEw ruling by the Council of Scientific and Industrial Research (CSIR) requiring the directors of its approximately 40 laboratories to quit after six years of service has thrown the agency, India's main research organization, into a crisis. One director has resigned, some are planning to take CSIR to court and most are rebelling against their director general, A. P. Mitra.

The provocation is a letter from CSIR headquarters in New Delhi informing the directors that under revised rules they have the option, after a non-renewable term of six years, of remaining as 'director-level' scientists or moving to CSIR headquarters.

Implementation of the rule comes two years after it was recommended by a review committee; CSIR laboratory directors protested at the time and hoped the new rule would not be put into practice. But their protests seem to have been in vain.

Enforcement of the six-year rule would require 20 of the $\mathbf{4 0}$ directors to leave their posts by next year. P. K. Ray, who resigned a \$60,000-a-year US job to become director of the industrial toxicology research centre, is one of many who have been asked to sign a new contract. So far only one has complied.

Some argue that the new letter is in breach of the previous contract, which did not specify a fixed tenure. Three directors are planning to fight CSIR in court and six are hoping to return to institutions which they left to join CSIR. P. K. Jena, director of the Regional Research Laboratory (RRL) in Bhubaneswar, resigned in disgust, and J. N. Barua, director of RRL in Jorhat, has refused to vacate his post although he has completed six years.

Pushpa Bhargava, director of the Centre for Cellular and Molecular Biology, has asked Prime Minister Rajiv Gandhi to intervene but with general elections due in November, Gandhi has little time to defuse what could be the biggest crisis in CSIR's 40-year history.

The directors say the crisis could have been averted had Mitra consulted them beforehand. He is also accused of favouritism in giving 'courtesy extensions' to five directors who have completed six years, while asking others to comply with the rule. But Mitra seems unperturbed. He has avoided meeting the directors or the press. K. S. Jayaraman 